\title{
TRIBOLOGY PROPERTIES EVALUATION FOR FRICTION PAIR Zn COATED STEEL -TICN MP COATED/UNCOATED TOOL STEEL
}

\author{
Emil Evin ${ }^{1)^{*}}$, Miroslav Tomáśs ${ }^{1)}$ \\ 1) Technical University of Košice, Faculty of Mechanical Engineering, Košice, Slovakia
}

Received: 12.11.2019

Accepted: 02.12.2019

*Corresponding author: e-mail: emil.evin@tuke.sk Tel.: +421 55602 3547, Department of Automotive Production, Faculty of Mechanical Engineering, Technical University of Košice, Letná 9, 04200 Košice, Slovakia

\begin{abstract}
When the sheet metal stamping processes are simulated, different values of the friction coefficient need to be defined in different regions, considering the nature of the deformation process. Thus, the regression and analytical models to determine the friction coefficient under the blank holder and on the die drawing edge by the strip drawing test are presented in the article. These models were verified by experimental strip drawing test under the same contact conditions. Zn coated high strength low alloyed steel sheet H220PD+Z100 was used at experiments and friction tests were done against the tool steel and TiCN MP coated tool steel. The results indicate, that values of friction coefficients evaluated by linear regression are lower than evaluated from analytical models. The positive effect of coating TiCN MP when applied on the contact surfaces was found, thus, decreases the friction coefficient and the drawing force scattering during the strip drawing test.
\end{abstract}

Keywords: deep drawing, strip drawing test, friction coefficient, experiment, analytical model

\section{Introduction}

There are many parameters influencing the sheet metal formability from the view of stamping, such as material properties, the die and the punch geometry, the contact surfaces' microgeometry, lubrication, etc. [1-5] Their accurate determination is ambiguous because these are changed from one case of the stamping process to another. Nowadays, simulation methods take place to predict their influence and to optimise the process parameters [6].

Because the simulations based on finite elements method becomes more and more important in pre-production, the accurate description of the input data is necessary. Besides constitutive equations describing material behaviour, contact conditions, i.e. friction coefficient on the contact surfaces needs to be defined as well. Sniekers [7] introduced the strip drawing test and method of data processing to calculate the friction coefficient at deep drawing. A new friction test method also presented Zhenyu [8]. Roizard [9] presented the improvement of strip drawing test emphasized to the influence of temperature effect, multi-pass, bulk plastic deformation. Kim [10] studied the pressure distribution in draw-bead friction test and its influence on the results of friction coefficient reached. Trzepieciński [11] studied the effect of sheet metal surface roughness, lubricant conditions and sheet orientation on the value of friction coefficient in sheet metal forming processes.

Nowadays, new coatings are applied on the contact surfaces in order to improve the contact conditions during deep drawing. Antoszewski et al. [12] tested electro spark (Cu+Ti) and (Mo-Ti) 
coatings applied on the tool steel by pin-on-dics test and their influence on friction. Severo et al. [13] tested in semi-industrial conditions by strip drawing test W-Ti-N coatings and they showed excellent results in comparison with uncoated tools. New trends are focused to the abandonment of lubricants in metal forming processes from the economic and ecological points of view. Vollertsen [14] defined the term dry metal forming and presented its benefits and state of the art in this field. Häfner [15] studied the lubricant-free tribological systems such as laser based surface modifications of tetrahedral amorphous carbon (ta-C) coatings in flat strip drawing test.

Fig. 1 Types of contacts at deep drawing

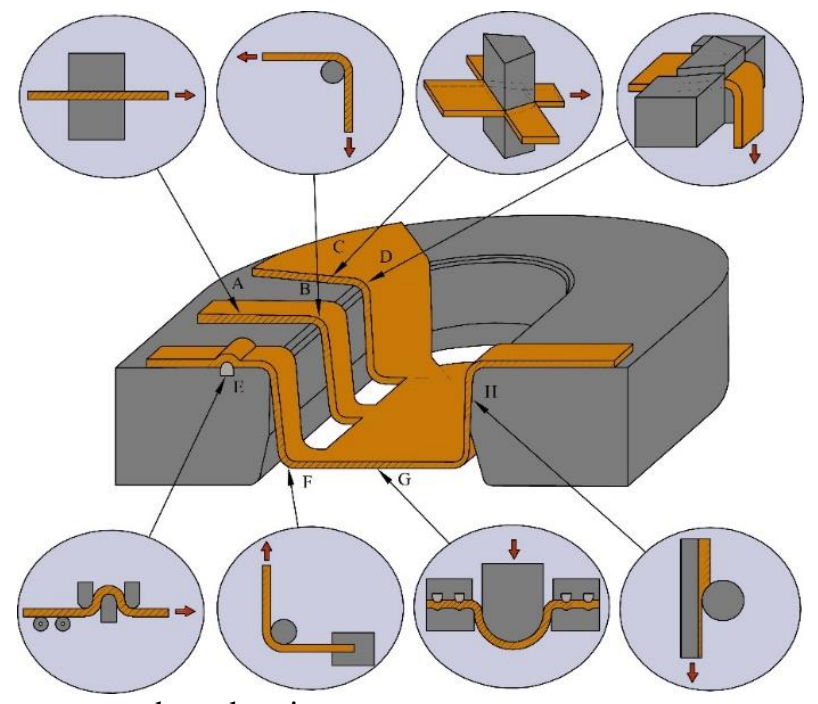

Stamping processes - deep drawing, stretching and bending - are characterized by different types of contact between the sheet metal and the die, as it is shown in Fig. 1: A - under the blank holder (bending or deep drawing of squared parts, blank is not deformed), B - on the drawing edge (blank is bend and drawn into the die, blank is deformed in radial direction and tangential deformation is negligible), $\mathrm{C}$ - corner of the stamped part under the blank holder (friction arises due to compressive tangential deformation when blank is drawn into the die), D - corner of the stamped part on the drawing edge (blank is deformed by the tensile radial and compressive tangential strains), E - the loading of contact surfaces in the drawing bead when it is applied to regulate the material flow in the straight parts, $\mathrm{F}$ - the loading of contact surfaces on punch drawing edge, $\mathrm{G}$ - stretching of the blank on the punch face, $\mathrm{H}$ - calibration of the part stamped. $[16,17]$

\section{Experimental material and methods}

High strength low alloyed steel sheet H220PD with thickness $\mathrm{a}_{0}=0.8 \mathrm{~mm}$ was used in experimental research and $\mathrm{Zn}$ coating $100 \mathrm{~g} . \mathrm{m}^{-2}$ was applied at both sides. Chemical composition is shown in Table 1 and the surface roughness parameters measured by Surftest SJ-301 were as follows: $\mathrm{Ra}=1.46 \pm 0.06 \mu \mathrm{m} ; \mathrm{RPc}=67 \pm 5 \mathrm{~cm}^{-1} ; \mathrm{Rz}=5.2 \pm 0.2 \mu \mathrm{m}$. Surface texture measured by Olympus BX51 M is shown in Fig. 2.

Table 1 Chemical composition of HSLA Zn coated steel H220PD + Z100 [wt \%]

\begin{tabular}{|c|c|c|c|c|c|c|c|}
\hline $\mathrm{C}$ & $\mathrm{Mn}$ & $\mathrm{Si}$ & $\mathrm{P}$ & $\mathrm{S}$ & $\mathrm{Al}$ & $\mathrm{Nb}$ & $\mathrm{Ti}$ \\
\hline 0.004 & 0.415 & 0.1 & 0.042 & 0.004 & 0.031 & 0.017 & 0.037 \\
\hline
\end{tabular}


Mechanical properties were measured by ISO 6892-1, normal anisotropy ratios by ISO 10113 at strain level of $20 \%$ and strain-hardening exponents by ISO 10275 within the strain range $5 \div 20 \%$. PC controlled TiraTEST 2300 testing machine with extensometers for both, the length and the width measurement was used with automated evaluation of properties shown in Table 2.

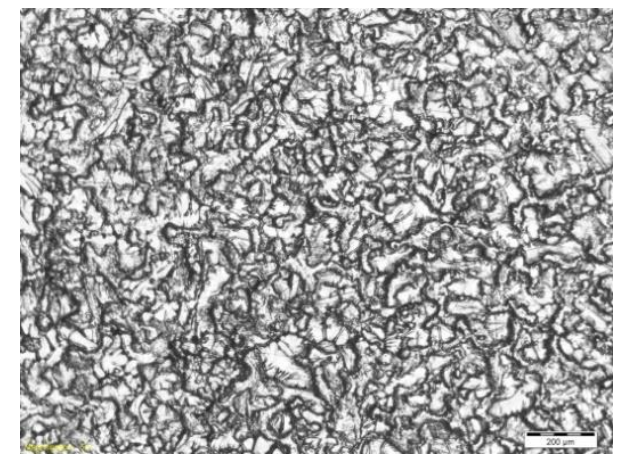

a)

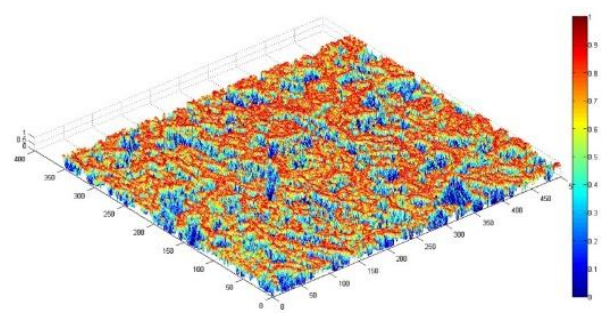

b)

Fig. 2 Surface texture of experimental material HSLA Zn coated steel H220PD + Z100 a) microscope 2D view, b) generated in Matlab 3D view

Table 2 Formability parameters of HSLA Zn coated steel H220PD + Z100

\begin{tabular}{|c|c|c|c|c|c|c|c|}
\hline $\begin{array}{c}\text { Dir. } \\
{\left[{ }^{\circ}\right]}\end{array}$ & $\begin{array}{c}\mathbf{R}_{\mathbf{p 0 . 2}} \\
{[\mathbf{M P a}]}\end{array}$ & $\begin{array}{c}\mathbf{R m} \\
{[\mathbf{M P a}]}\end{array}$ & $\begin{array}{c}\mathbf{A}_{\mathbf{g}} \\
{[\mathbf{\%}]}\end{array}$ & $\begin{array}{c}\mathbf{A} \mathbf{8 0} \\
{[\mathbf{\%}]}\end{array}$ & $\begin{array}{c}\mathbf{K} \\
{[\mathbf{M P a}]}\end{array}$ & $\begin{array}{c}\mathbf{n} \\
{[-]}\end{array}$ & $\begin{array}{c}\mathbf{r} \\
{[-]}\end{array}$ \\
\hline 0 & 214 & 375 & 24 & 40 & 677 & 0.24 & 1.21 \\
\hline 45 & 217 & 359 & 26 & 42 & 651 & 0.23 & 1.76 \\
\hline 90 & 223 & 368 & 23 & 38 & 658 & 0.23 & 1.75 \\
\hline
\end{tabular}

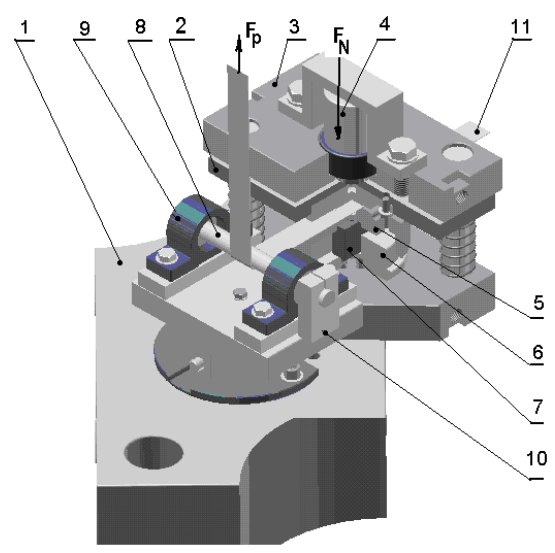

a)

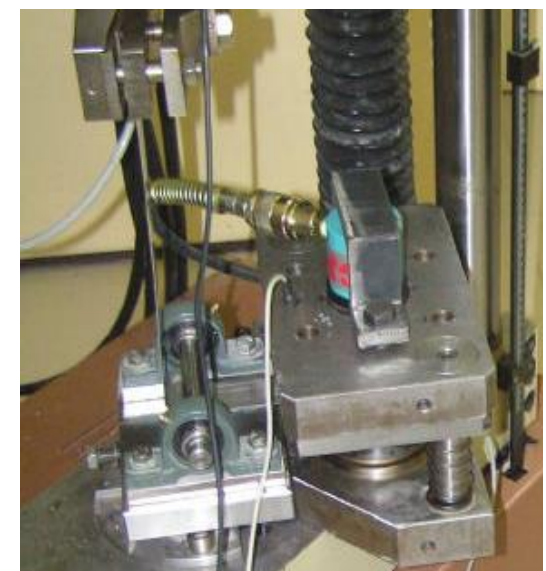

b)

Fig. 3 The friction simulator - strip drawing test: a) model, b) real view 1 - base plate, 2 - midplate, 3 - upper plate, 4 - clamping cylinder, 5 - upper grip, 6 - lower grip, 7 - blank-holding force cell, 8 - roller, 9 - ball bearings, 10 - roller brake, 11 - strip

The friction simulator shown in Fig. 3 was used to study friction in a stamping process. This simulator enables modelling the stress state of flat (Fig. 1-A) and curved regions (Fig. 1-B). 
Processes on the contact areas can be investigated separately or combined. The roller can be fixed or free rotated. If the movement of roller is not blocked, we model the loading of die contact areas under blank holder between flat surfaces (Fig. 1-A). In the case the roller is fixed we model the loading of curved contact areas on the die drawing edge (Fig. 1-B).

Drawing conditions were as follows: blank holding forces $\mathrm{F}_{\mathrm{N}}=2 ; 4 ; 6$ and $8 \mathrm{kN}$, strip drawing speed $\mathrm{v}=10 \mathrm{~mm} / \mathrm{s}$, strip width $50 \mathrm{~mm}$, grips' contact area 20x50 mm. Both, grips and roller of the friction tester were made from tool steel 1.2379, hardened to $63 \mathrm{HRc}$ and polished to $\mathrm{Ra}=$ $0.32 \pm 0.05 \mu \mathrm{m}$. During the test, exchangeable grips were used and this allowed modelling friction conditions tool steel/Zn surface and TiCN MP coating/Zn surface. Thus, TiCN MP coating was applied on the grips and the roller as well to research the influence of coating to the friction coefficient.

Adhesion and other properties of TiCN MP coating were measured by series of tests. Coating thickness $3.19 \mu \mathrm{m}$ was measured by Calotest method (Fig. 4), microhardness $\mathrm{H}_{\mathrm{IT}}=51 \mathrm{GPa}$ and modulus $\mathrm{E}=480 \mathrm{GPa}$ by indentation tester TTX-NHT S/N with Berkovich diamond indenter at $60 \mathrm{mN}$ load, sinusoidal frequency $15 \mathrm{~Hz}$ and amplitude $6 \mathrm{mN}$, holding time 10s. Coating adhesiveness measured by Mercedes test was HF1 (Fig. 5) and Scratch test confirmed good adhesion and compactness by acoustic emissivity $0.8 \mathrm{~V}$ and the cohesive failure were found at the force $\mathrm{L}_{\mathrm{C} 1}=34.7 \pm 4.0 \mathrm{~N}$, adhesion failure and spallation of the coating was found at the force $\mathrm{L}_{\mathrm{C} 2}$ $=41.6 \pm 2.6 \mathrm{~N}$ and critical force to surface exposure at the centre of the track $\mathrm{L}_{\mathrm{c} 3}=86.1 \pm 2.9 \mathrm{~N}$ - Fig 6.

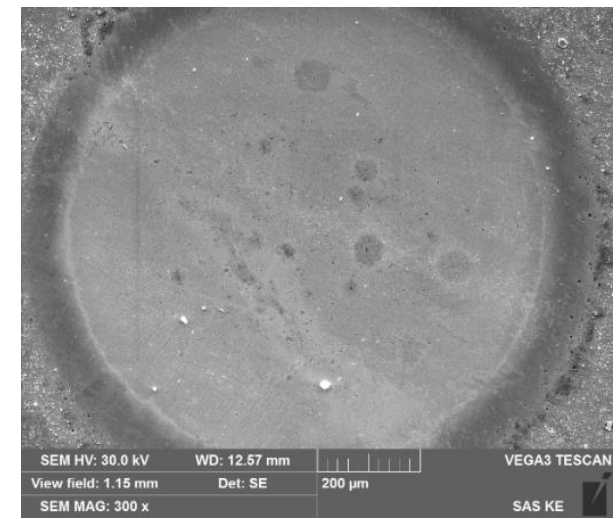

Fig. 4 TiCN MP coating thickness measurement (Calotest method)

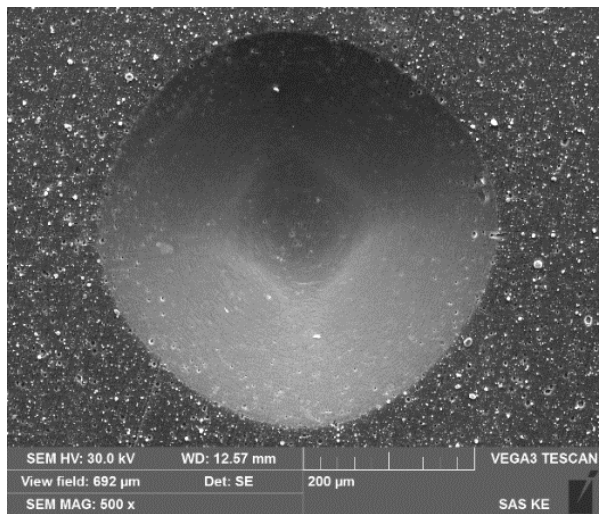

Fig. 5 Mercedes test result for TiCN MP coating

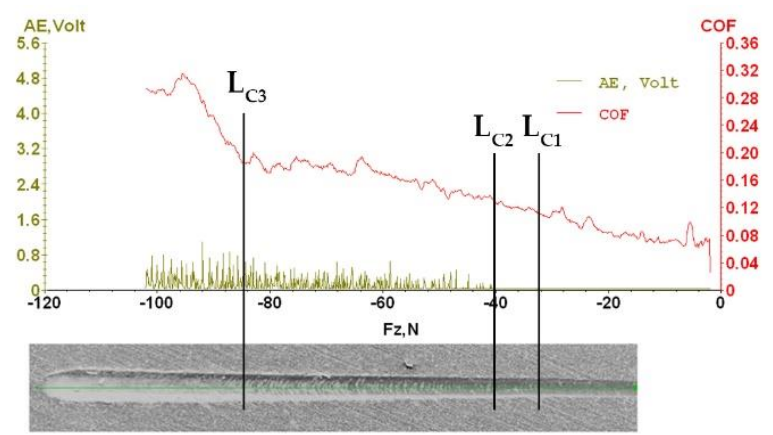

Fig. 6 Scratch test result for TiCM MP coating 
Surface roughness after coating deposition measured by Surftest SJ-201 was as follows: Ra $=0.24$ $\pm 0.04 \mu \mathrm{m}$ and $\mathrm{Rz}=2.78 \pm 0.15 \mu \mathrm{m}$ when measured in grinding direction (i.e. longitudinal) and $\mathrm{Ra}=0.20 \pm 0.05 \mu \mathrm{m}$ and $\mathrm{Rz}=2.40 \pm 0.11 \mu \mathrm{m}$ when measured perpendicular to the grinding direction (i.e. transverse).

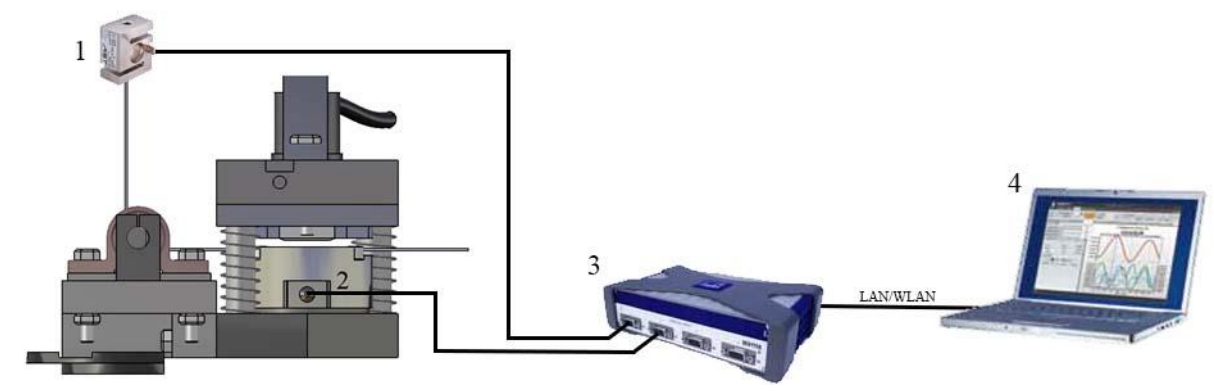

Fig. 7 Measuring system at strip drawing test

The drawing force and the blankholding force were measured during the strip drawing test. Measuring system (Fig. 7) consisted of force load cells KAS 20 (1) and KF 20 K (2), tensometric measuring unit QuantumX MX440A (3) and software Catman Easy (4).

Record of drawing and blankholding forces is shown in Fig. 8 and Fig. 9 in the next chapter. From experimentally measured values of drawing and blankholding forces the friction coefficient can be determined in the area under blankholder and on the die drawing edge also. Two methods were applied for evaluation of friction coefficient in the area under blankholder.

In the first method the regression analysis was used [16, 17, 18]. The relation between blankholding force and drawing force can be described as follows:

$\Delta \mathrm{F}_{\mathrm{p}(\mathrm{f} 3=0)}=$ Intercept $+\Delta \mathrm{F}_{\mathrm{N} 1,2}($ Slope $)$

where: $\Delta \mathrm{F}_{\mathrm{p}(\mathrm{f} 3=0)}[\mathrm{N}]$ - the difference of drawing forces,

$\Delta \mathrm{F}_{\mathrm{N} 1,2}[\mathrm{~N}]$ - the difference of blanholding forces $\mathrm{F}_{\mathrm{N} 2}-\mathrm{F}_{\mathrm{N} 1}, \mathrm{~F}_{\mathrm{N} 2}>\mathrm{F}_{\mathrm{N} 1}$.

Drawing forces increases with the increase of blankholding forces. Thus, the friction coefficient $\mathrm{f}_{1,2}$ is calculated as half value of slope:

$\mathrm{f}_{1,2}=\frac{\text { Slope }}{2}$

where: $\mathrm{f}_{1,2}[-]$ - the mean friction coefficient between die and strip.

The second method comes out from analytical models based on measurement of forces during strip drawing test $[17,18,19]$. When the roller on the friction simulator is not blocked (friction model under the blankholder), the friction coefficient $\mathrm{f}_{1,2}$ is calculated as follows:

$\mathrm{f}_{1,2}=\frac{\mathrm{F}_{\mathrm{p} 2(\mathrm{f} 3=0)}-\mathrm{F}_{\mathrm{p} 1, \mathrm{ref}(\mathrm{f} 3=0)}}{2\left(\mathrm{~F}_{\mathrm{N} 2}-\mathrm{F}_{\mathrm{N} 1, \mathrm{ref}}\right)}=\frac{\Delta \mathrm{F}_{\mathrm{p} 1,2(\mathrm{f} 3=0)}}{2 \cdot \Delta \mathrm{F}_{\mathrm{N} 1,2}}$

where: $F_{\mathrm{N} 1, \mathrm{ref}}=2000 \mathrm{~N}$,

$\mathrm{F}_{\mathrm{N} 2}[\mathrm{~N}]$ - the blankholding force $\left(\mathrm{F}_{\mathrm{N} 1, \mathrm{ref}}<\mathrm{F}_{\mathrm{N} 2}\right)$,

$\mathrm{F}_{\mathrm{p} 2(\mathrm{f} 3=0)}[\mathrm{N}]$ - the drawing force generated by blankholding force $\mathrm{F}_{\mathrm{N} 2}$,

$\mathrm{F}_{\mathrm{p} 1, \mathrm{ref}(\mathrm{f} 3=0)}[\mathrm{N}]$ - the drawing force generated by blankholding force $\mathrm{F}_{\mathrm{N} 1 \text {,ref. }}$ 
When the roller on the friction simulator is blocked (friction model on the die drawing edge), the friction coefficient $\mathrm{f}_{3}$ is calculated as follows:

$$
\mathrm{f}_{3}=\ln \left(\frac{\mathrm{F}_{\mathrm{p}(\mathrm{f} 3>0)}}{\mathrm{F}_{\mathrm{p}(\mathrm{f} 3=0)}}\right) \frac{2}{\pi}
$$

where: $F_{p(f 3=0)}[N]-$ the drawing force generated by a rotating roller,

$\mathrm{F}_{\mathrm{p}(\mathrm{f} 3>0)}[\mathrm{N}]$ - the drawing force generated by a fixed roller,

$\mathrm{f}_{3}[-]$ - the friction coefficient on the die drawing edge.

\section{Results and discussion}

Table 3 shows set values of blankholding forces $F_{N}$ and measured values of drawing forces $F_{p(f 3=0)}$ and $F_{p(f 3>0)}$. As it is shown in Fig. 8 and Fig. 9, there was scattering in drawing force for specific pressure over $4 \mathrm{MPa}$ when measured for friction pair tool steel / Zn surface and over $8 \mathrm{MPa}$ when measured for friction pair TiCN MP / Zn surface. Thus, the average values of forces were evaluated beyond the $60 \mathrm{~s}$ to exclude initial bending of the strip.

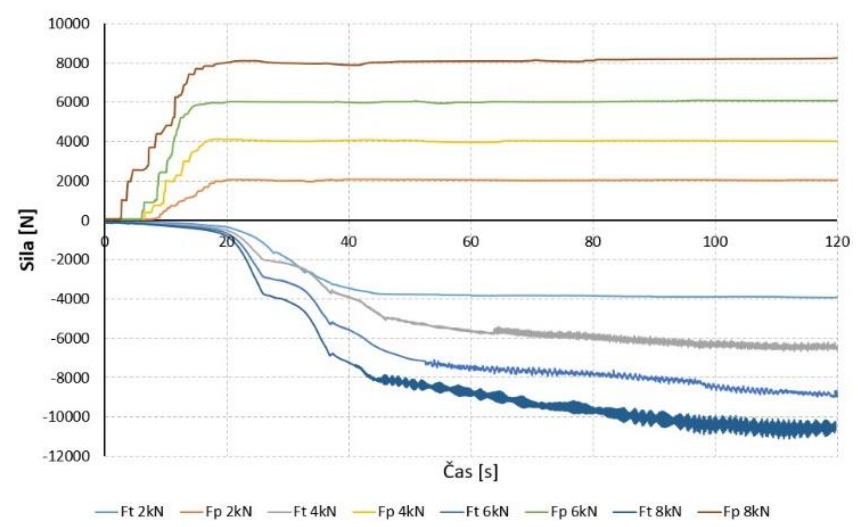

Fig. 8 Record of the drawing and blankholding forces at strip drawing test for friction pair tool steel / Zn surface

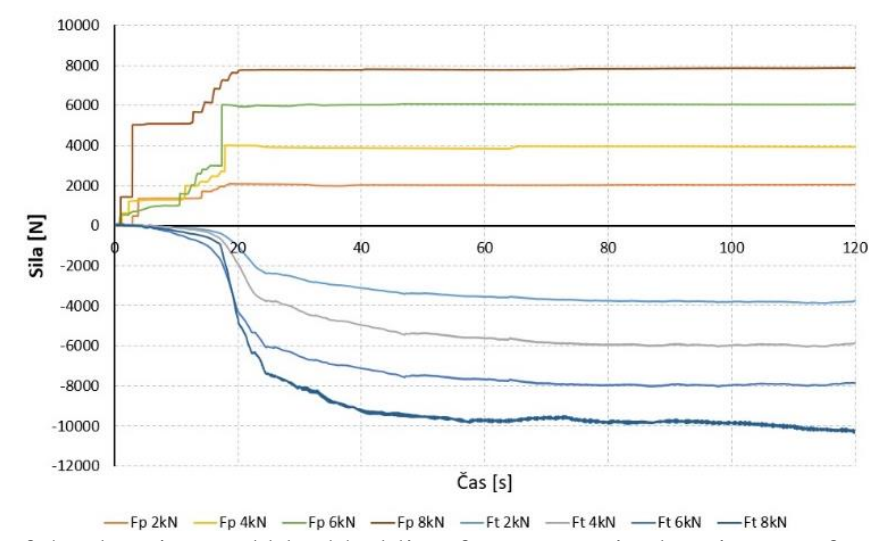

Fig. 9 Record of the drawing and blankholding forces at strip drawing test for friction pair TiCN MP / Zn surface 
Table 3 Measured values of forces and calculated values of friction coefficient - no lubricant

\begin{tabular}{|c|c|c|c|c|c|c|c|}
\hline \multirow[t]{2}{*}{ Friction pair } & \multirow{2}{*}{$\begin{array}{l}\text { Normal } \\
\text { force } \\
\text { F }_{N}[\mathbf{N}]\end{array}$} & \multirow{2}{*}{$\begin{array}{l}\text { Specific } \\
\text { pressure } \\
\text { p [MPa] }\end{array}$} & \multicolumn{2}{|c|}{$\begin{array}{c}\text { Drawing force } F p \\
{[N]}\end{array}$} & \multicolumn{3}{|c|}{ Friction coefficient f [-] } \\
\hline & & & $\mathbf{f}_{3}=\mathbf{0}$ & $\mathbf{f}_{3}>\mathbf{0}$ & $\begin{array}{l}f_{1,2} \\
\text { Eq. } \\
(2 .) \\
\end{array}$ & $\begin{array}{l}\mathbf{f}_{1,2} \\
\text { Eq. } \\
(3 .)\end{array}$ & $\begin{array}{c}\mathbf{f}_{3} \\
\mathbf{E q} . \\
(4 .) \\
\end{array}$ \\
\hline \multirow{4}{*}{$\begin{array}{c}\text { H220PD+Z100 } \\
- \\
\text { Tool steel }\end{array}$} & 2039 & 2 & 2280 & 3816 & \multirow{4}{*}{0.304} & & 0.328 \\
\hline & 4033 & 4 & 3689 & 6075 & & 0.353 & 0.318 \\
\hline & 6068 & 6 & 4931 & 8447 & & 0.329 & 0.343 \\
\hline & 8121 & 8 & 6178 & 10119 & & 0.320 & 0.314 \\
\hline \multirow{4}{*}{$\begin{array}{c}\mathrm{H} 220 \mathrm{PD}+\mathrm{Z} 100 \\
- \\
\mathrm{TiCN}\end{array}$} & 2032 & 2 & 2310 & 3741 & \multirow{4}{*}{0.296} & & 0.307 \\
\hline & 4030 & 4 & 3580 & 5905 & & 0.318 & 0.319 \\
\hline & 6047 & 6 & 4779 & 7874 & & 0.307 & 0.318 \\
\hline & 8050 & 8 & 5963 & 9950 & & 0.304 & 0.326 \\
\hline
\end{tabular}

When evaluated from Eq. (2.), the friction coefficient for friction pair tool steel $-\mathrm{Zn}$ surface was 0.304 and for friction pair TiCN MP coating / Zn surface it was 0.296 . When friction coefficient evaluated under the blank holder according to Eq. (3.), it varied from 0.320 to 0.353 , i.e. $0.334 \pm$ 0.017 for friction pair tool steel / $\mathrm{Zn}$ surface; and from 0.304 to 0.318 , i.e. $0.310 \pm 0.007$ for friction pair TiCN coating / $\mathrm{Zn}$ surface. When friction coefficient evaluated on the drawing edge according to Eq. (4.), it varied from 0.314 to 0.343 . i.e. $0.326 \pm 0.013$ for friction pair tool steel / $\mathrm{Zn}$ surface; and from 0.307 to 0.326 , i.e. $0.317 \pm 0.008$.

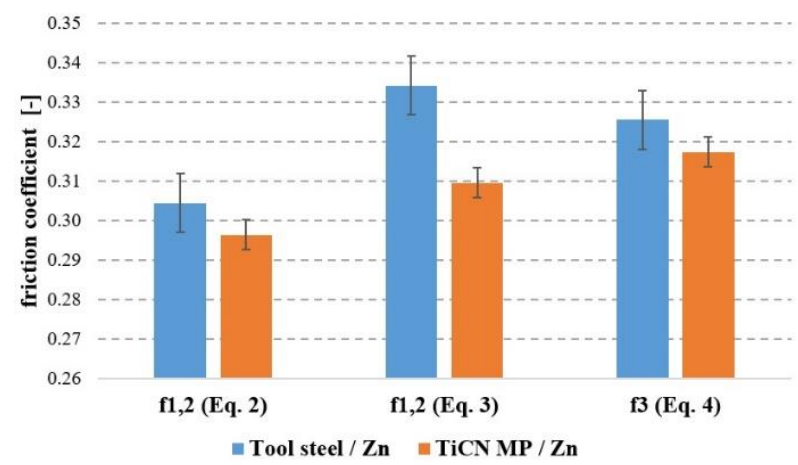

Fig. 10 Comparison of friction coefficient calculated by linear regression (Eq. 2.) and from analytical models (Eq. 3. and Eq. 4.)

The average values of friction coefficient calculated from Eq. (2.), Eq. (3.) and Eq. (4.) are shown and compared in Fig. 10. The lowest average value of the friction coefficient was reached when calculated from Eq. (2.), but the average friction coefficient under the blank holder calculated from Eq. (3.) and on the die drawing edge calculated from Eq. (4.) are higher. As supposed in the $[16,18]$, Eq. (2.) gives the averaged friction coefficient and the method is not suitable to evaluate the friction coefficient in different regions.

There were found lower values of friction coefficient for friction pair TiCN MP / Zn coating when calculated from each equation. The results partially comply to the roughness measurement, when lower roughness was identified on the grips after coating the tool steel with TiCN MP coating. Decrease in roughness after coating was reached by Choi [20] also, while Merklein [21] confirmed decreasing the friction coefficient measured at dry conditions for smooth and polished surfaces. 
As it is shown in Fig. 8, scattering occurred in the drawing force if the normal force is higher than $4 \mathrm{kN}$ (i.e. specific pressure under the blankholder $4 \mathrm{MPa}$ ) when measured for friction pair tool steel / Zn surface. In the case of friction pair TiCN MP coating / Zn surface in Fig. 9, scattering in the drawing force occurred only if the normal force $8 \mathrm{kN}$ (i.e. specific pressure under the blank holder $8 \mathrm{MPa}$ ) was applied. Roizard in [9] stated the scattering is a result of stick-slip sliding regime at low velocities when the static frictional is nonzero. Considering mentioned and the strip velocity $10 \mathrm{~mm} \cdot \mathrm{s}^{-1}$, the effect of the TiCN MP coating resulted in a reduction of scattering the drawing force for specific pressure 4 and $6 \mathrm{MPa}$ and the amplitude of scatters decreased for higher specific pressure $8 \mathrm{MPa}$.

The contact pressure is one of the parameters influencing the friction [22]. When the friction coefficient $f_{1,2}$ calculated from Eq. (3.), i.e. under the blank holder, its value decreases with the contact pressure. The same tendency was found by Trzepiecinski [23] for the strip drawing test performed. But contrary to the results [22] and [23], the dependence of friction coefficient $f_{3}$ calculated from Eq. (4.), i.e. on the die drawing edge, on the contact pressure is not unequivocal for both friction pairs tested.

\section{Conclusions}

Nowadays, lubricant free sheet metal stamping processes appears being a challenge. Besides ecology point of view, economic aspects are also important due to avoid degreasing the stampings. Thus, the article is focused to the friction coefficient measurement under the dry condition for friction pair tool steel / Zn surface and TiCN MP coated tool steel / Zn surface. While the friction coefficient under the blank holder evaluated by linear regression gives the average value, analytical models allow calculating the friction coefficient under the blank holder and on the die drawing edge as well. The effect of TiCN MP coating applied on the tool steel resulted in lower friction coefficients and minimizing the drawing force scattering. Further research will focus to the galling phenomena and verification the results by the simulation.

\section{References}

[1] K. Lange: Umformtechnik - Handbuch fur Industrie und Wissenschaft, second ed., Springer/Verlag, Berlin, 2002

[2] J. Bilík, V. Titel, M. Dobisova, R. Suba: Research Papers FMSaT in Trnava, Slovak University of Technology in Bratislava, Vol. 27, 2009, p. 15-20.

[3] O. Mahrenholtz, N. Bontcheva, R. Iankov: Journal of Materials Processing Technology, Vol. 159, Issue 1, 2005, p. 9-16, https://doi.org/10.1016/j.jmatprotec.2003.10.009

[4] T. Kvačkaj et al.: Archives of Metallurgy and Materials, Vol. 58, Issue 2, 2013, p. 407-412, https://doi.org/10.2478/amm-2013-0008

[5] P. Petroušek et al.: Acta Metallurgica Slovaca, Vol. 21, No. 3, 2015, p. 176-183, http://dx.doi.org/10.12776/ams.v21i3.615

[6] A. Schrek, P. Švec, A. Brusilová, Z. Gábrišová: Strojnicky Casopis, Vol. 68, Issue 1, 2018, p. 95-102, https://doi.org/10.2478/scjme-2018-0010

[7] R. J. J. M. Sniekers, H. A. A. Smits: Journal of Materials Processing Technology, Vol. 66, Issues 1-3, 1997, p. 216-223, https://doi.org/10.1016/S0924-0136(96)02526-5

[8] H. Zhenyu, F. Vollertsen: Journal for Technology of Plasticity, Vol. 29, 2004, p.1-9

[9] X. Roizard, J.M. Pothier, J.Y. Hihn, G. Monteil: Journal of Mat. Processing Technology, Vol. 209, Issue 3, 2009, p. 1220-1230, https://doi.org/10.1016/j.jmatprotec.2008.03.023 
[10] Y. S. Kim, M. K. Jain, D. R. Metzger: Non- uniform Pressure Distribution in Draw- Bend Friction Test and its Influence on Friction Measurement. In: AIP Conference Proceedings 778, 661 (2005), https://doi.org/10.1063/1.2011298

[11] T. Trzepieciński: International Journal of Automotive Technology, Vol. 16, Issue 5, 2015, p. 849-863, http://dx.doi.org/10.1007/s12239-015-0087-1

[12] B. Antoszewski, E. Evin, J. Audy: Journal of Tribology, Vol. 130, Issue 2, 2008, p. 021303 1 -021303-6, https://doi.org/10.1115/1.2842296

[13] Severo et al.: Journal of Materials Processing Technology, Vol. 209, Issue 10, 2009, p. 46624667, https://doi.org/10.1016/j.jmatprotec.2008.11.040

[14]F. Vollertsen, F. Schmidt: Int. Journal of Precision Engineering and Manufacturing-Green Technology, Vol. 1, Issue 1, 2014, p. 59-62, https://doi.org/10.1007/s40684-014-0009-0

[15] T. Häfner et al.: Journal of Laser Micro/Nanoengineering, Vol. 12, No. 2, 2017, p. 132-140, https://doi.org/10.2961/jlmn.2017.02.0015

[16] A. Hrivnak, E. Evin: Formability of steel sheets, first ed., Elfa, Košice, 2004

[17]E. Evin, M. Tomáš, M. Výrostek: Acta Mechanica Slovaca, Vol. 20, Issue 1, 2016, p. 14-21, https://doi.org/10.21496/ams.2016.003

[18] J. Audy, E. Evin: MM Science Journal, Vol. 6, 2008, p. 20-23, https://doi.org/10.17973/MMSJ.2008_06_20080601

[19]E. Evin, M. Tomáš, M. Kollárová, B. Antoszewski: Acta Metallurgica Slovaca, Vol. 20, No. 2, 2014, p. 189-199, http://dx.doi.org/10.12776/ams.v20i2.298

[20]H. S. Choi et al.: International Journal of Precision Engineering and Manufacturing, Vol. 15, Issue 6, 2014, p. 1101-1107, https://doi.org/10.1007/s12541-014-0443-5

[21]M. Merklein, K. Andreas, J. Steiner: International Journal of Precision Engineering and Manufacturing-Green Technology, Vol. 2, Issue 2, 2015, p. 131-137, https://doi.org/10.1007/s40684-015-0017-8

[22] Y. S. Kim, M. K. Jain, D. R. Metzger: Int. Journal of Machine Tools \& Manufacture, Vol. 56, May 2012, p. 69-78, https://doi.org/10.1016/j.ijmachtools.2011.12.011

[23] T. Trzepieciński: Metals, No. 9, Issue 9, 2019, 988, https://doi.org/10.3390/met9090988

\section{Acknowledgements}

Authors are grateful for the support of experimental works by projects APVV-0273-12 "Supporting innovations of autobody components from the steel sheet blanks oriented to the safety, the ecology and the car weight reduction", VEGA 2/0800/19 "Prediction of weldability and formability for laser welded tailored blanks made of combined high strength steels with CAE support" and APVV-17-0381 "Increasing the efficiency of forming and joining parts of hybrid car bodies". 